\title{
CLIMATE CHANGE and THE RULE OF LAW: ADJUDICATING THE FUTURE IN INTERNATIONAL LAW
}

PUBLIC LECTURE

\section{United Kingdom Supreme Court}

17 September 2015, 530 pm

PHILIPPE SANDS QC ${ }^{1}$

Professor of Law, University College London

(a) philippesands

\section{CHECK AGAINST DELIVERY}

\section{EMBARGOED UNTIL 6 PM, 17 SEPTEMBER 2015}

My Lords and Ladies, ladies and gentlemen,

\section{PART I: INTRODUCTION}

Three years ago I attended a meeting of a small group of ambassadors at the United Nations in New York. The context was an initiative by the small, low-lying island State of Palau to persuade the UN General Assembly to ask the International Court of Justice in The Hague to give an Advisory Opinion, on the responsibilities of States under international law to ensure that activities carried out under their jurisdiction or control that emit greenhouse gases do not damage other States. ${ }^{2}$

\footnotetext{
${ }^{1}$ In preparing this lecture I have been greatly assisted by Luis Viveros, $\mathrm{PhD}$ candidate at UCL, and by the very fine conference paper authored by Emily Barritt, Liz Fisher and Eloise Scotford, 'Adjudicating the Future: Climate Change and Legal Disruption' (2015, unpublished)

${ }^{2}$ Press Conference on Request for International Court of Justice Advisory Opinion on Climate Change (3 February 2012) <http://www.un.org/press/en/2012/120203_ICJ.doc.htm> accessed 3 January 2016
} 
Are you in favour of such an initiative, I was asked. I was not, I replied.

I explained why. I doubted that the ICJ would give an Advisory Opinion that might be helpful to Palau, or indeed to the world as a whole. There was a serious risk that the Court might offer an opinion that was unhelpful: it could, for example, decline to give an Opinion at all (a path implying that international law had nothing to say), or it could give an opinion that was unhelpful on the science, or unhelpful on the law.

It was also possible that the Court could give an answer that might elucidate the relevant rules of international law, and be helpful on the science, and that such a contribution might generate a greater political will to action by states. Yet as matters then stood I thought that to be an unlikely prospect, having regard to the practise of the Court. The Court had given a reasonably robust Opinion on the illegality of Israel's Wall, ${ }^{3}$ but in other cases it had skirted around the difficult issues that really mattered, in the face of political divisions. In the Advisory Opinion on Nuclear Weapons, for example, the Court ruled (by the narrowest of possible majorities) that it "cannot conclude definitively whether the threat or use of nuclear weapons would be lawful or unlawful in an extreme circumstance of self-defence, in which the very survival of a State would be at stake", in view of "the current state of international law, and of the elements of fact at its disposal". ${ }^{4}$ That unhappy conclusion - you might be acting lawfully in extinguishing others if you yourself face extinction - did not seem to bode well for the climate change issue.

Similarly, the Advisory Opinion on Kosovo's purported declaration of independence failed to offer a definitive solution to a divisive problem, $\stackrel{5}{\text { and }}$ in a case arising under the Convention on the Elimination of Racial Discrimination (brought by Georgia against Russia in relation to Abkhazia and South Ossetia) the Court declined to exercise jurisdiction at all ${ }^{6}$ (a green light of sorts to the absence of judicial scrutiny in other Russian overseas

${ }^{3}$ Legal Consequences of the Construction of a Wall in the Occupied Palestinian Territory (Advisory Opinion) ICJ Rep 2004. ${ }^{4}$ Legality of the Threat or Use of Nuclear Weapons (Advisory Opinion) ICJ Rep 1996 [105(2)(E)]..

${ }^{5}$ Accordance with International Law of the Unilateral Declaration of Independence in Respect of Kosovo (Advisory Opinion) ICJ Rep 2010

${ }^{6}$ Case Concerning Application of the International Convention on the Elimination of all Forms of Racial Discrimination (Georgia v. Russia) Preliminary Objections ICJ Rep 2011. 
adventures). It might be a better prospect, I suggested, to think about the International Tribunal for the Law of the Sea, where a more robust (but politically less influential) decision might be obtained, assuming that Tribunal could gave an advisory opinion at all (at that time ITLOS had never been asked to give an opinion under Article 138 of its Rules).

A few years on, my perspective as to the Court's potential role on climate change has evolved. Several factors have combined. There have been changes in public opinion, and the Pope has issued a strong encyclical letter (Laudato Si'), framing the issue of climate change in moral terms. ${ }^{7}$ The scientific evidence appears (to a non-scientist) to be ever more robust. More governments are taking more actions, and even the United States and China seem finally to be acting, jointly announcing targets to cut greenhouse gas emissions in the next ten to fifteen years. ${ }^{8}$ National courts are starting to act: in June this year the Rechtbank, a court in The Hague, ruled the Dutch Government's climate change policy was unlawful in failing to achieve the 2020 greenhouse gas emission target reduction (of 25\% to 40\%), a target supported by scientific evidence against the background of a global commitment to reduce global greenhouse gas emissions so as to hold the increase in global average temperature below $2{ }^{\circ} \mathrm{C}$ above pre- industrial levels. ${ }^{9}$ And there is the more recent practise of the ICJ, a point to which I shall return.

If a court in the Netherlands is willing to act - I appreciate the judgment is now being appealed - then could not an international court also make a useful contribution?

To answer that question requires us to delve into the nature of international law - of limited legislative specificity - and international courts - which have tended to be followers rather than leaders, although not always.

\footnotetext{
7 'Encyclical Letter Laudato Si' of the Holy Father Francis on Care of Our Common Home' S. 1 $<$ https://w2.vatican.va/content/dam/francesco/pdf/encyclicals/documents/papafrancesco_20150524_enciclica-laudato-si_en.pdf $>$ accessed 3 January 2016

8 The U.S. new emissions target is 26-28\% below 2005 levels by 2025, China's target is to peak CO2 emissions by 2030, coupled with a non-fossil fuel share of all energy of roughly $20 \%$ by 2030 <https://www.whitehouse.gov/the-press-office/2014/11/11/fact-sheet-us-china-joint-announcementclimate-change-and-clean-energy-c $>$ accessed 3 January 2016
9 Rechtbank Den Haag (24 June 2015) C/09/456689 (English translation) <http://uitspraken.rechtspraak.nl/inziendocument?id=ECLI:NL:RBDHA:2015:7196> accessed 3 January 2016
} 


\section{PART II: INTERNATIONAL LAW AND CLIMATE CHANGE}

I begin with a few words about international law and climate change.

I was in Chantilly, Virginia, back in February 1991, when the first meeting of the Intergovernmental Negotiating Committee on Climate Change took place. The gathering took place against the backdrop of Iraq's invasion of Kuwait. It was obvious to all in the room that consensus on the need for action was not immediately in evidence.

Yet a year later the framework Convention on Climate Change was adopted at the Rio Conference in June 1992. ${ }^{10}$ It had no targets or timetables, but its Article 2 provided that the Convention's "ultimate objective" was "stabilization of greenhouse gas concentrations in the atmosphere at a level that would prevent dangerous anthropogenic interference with the climate system". What does that mean? You may well ask, and perhaps one day an international court will offer an answer. In 1997 the Kyoto Protocol provided for certain countries to cut their emissions, with specific targets. ${ }^{11}$ In 2010, at a meeting in Cancun, the Conference of the Parties to the 1992 Convention went further, recognizing the need for "deep cuts in global greenhouse gas emissions ... with a view to reducing global greenhouse gas emissions so as to hold the increase in global average temperature below $2{ }^{\circ} \mathrm{C}$ above preindustrial levels". This target was identified as the "long-term goal, consistent with science and on the basis of equity". ${ }^{12}$

No doubt these and other actions have had some consequences: some emissions have been curtailed, in some parts of the world, some new policies and actions taken, some change of consciousness initiated.

\footnotetext{
${ }^{10}$ United Nations Framework Convention on Climate Change (adopted 9 May 1992) 1771 UNTS I-30822 (UNFCCC). For an overview of the international legal framework see Philippe Sands and Jacqueline Peel, Principles of International Environmental Law (3rd edn, CUP 2012) 274-298.

${ }^{11}$ Kyoto Protocol to the United Nations Framework Convention on Climate Change (adopted 11 December 1997) 2303 UNTS A-30822.

12 Report of the Conference of the Parties on its sixteenth session, held in Cancun from 29 November to 10 December 2010, FCCC/CP/2010/7/Add.1, 15 March 2011 [4]
} 
Yet much more seems to be needed.

The most recent evidence, as set out by the IPCC last year, is clear, without ambiguity, even startling. I quote from the 2014 Synthesis Report:

- "Human influence on the climate system is clear ... recent climate changes have had widespread impacts on human and natural systems"

- "many of the observed changes are unprecedented"

- "the atmosphere and ocean have warmed, the amounts of snow and ice have diminished, and sea level has risen"

- anthropogenic greenhouse gas emissions "are extremely likely to have been the dominant cause of the observed warming since the mid-20th century"

- "Continued emissions ... will cause further warming and long-lasting changes ... increasing the likelihood of severe, pervasive and irreversible impacts"

- "Limiting climate change would require substantial and sustained reductions in greenhouse gas emissions"

- "It is very likely that heat waves will occur more often and last longer, and that extreme precipitation events will become more intense and frequent in many regions. The ocean will continue to warm and acidify, and global mean sea level to rise."

- "Many aspects of climate change and associated impacts will continue for centuries"

- "The risks of abrupt or irreversible changes increase as the magnitude of the warming increases."

- "Without additional mitigation efforts ... warming by the end of the 21 st century will lead to high to very high risk of severe, wide- spread and irreversible impacts globally"

- "There are multiple mitigation pathways that are likely to limit warming to below $2^{\circ} \mathrm{C}$ relative to pre-industrial levels. These pathways would require substantial emissions reductions over the next few decades and near zero 
emissions of $\mathrm{CO} 2$ and other long-lived greenhouse gases by the end of the century". ${ }^{13}$

These are not the words of doubt. They indicate that we have gone well beyond the classical standards on the burden of legal proof, whether it be balance of probabilities, or beyond reasonable doubt, or the standard of 'conviction intime' that I am directed to apply by Swiss law sitting as an arbitrator at the Court of Arbitration for Sport in Lausanne. Just this week the UK Met Office issued a new report, entitled Big Changes Underway in the Climate System? We are told that in 2015 the earth's average surface temperature is running at or near record levels. ${ }^{14}$

Scientific evidence tells us that climate change is happening; the textbooks tell us that it's a subject for international law, one addressed by treaties and other international instruments.

It is plain that climate change poses significant challenges to international law (and to international courts). The subject transcends the classical structure of an international legal order that divides our planet into territorially defined areas over which States are said to have sovereignty. Issues associated with climate change permeate national boundaries: emissions or actions in one state will have adverse consequences in another, and in areas over which states have no jurisdiction or sovereignty. Climate change is not the only issue in which this occurs: one thinks of the protection of the ozone layer, ${ }^{15}$ for example, or the protection of the oceans, ${ }^{16}$ as matters requiring concerted global action. Yet there is no other issue like climate change, where the sources of the problem - according to the IPCC - are so many and so broad, requiring actions that touch upon virtually every aspect of human endeavour and action. Each of us contributes to climate change, each of us will be affected by climate change.

13 IPCC, 'Climate Change 2014 Synthesis Report: Summary for Policymakers' (2014) 2-20 < http://www.ipcc.ch/pdf/assessment-report/ar5/syr/AR5_SYR_FINAL_SPM.pdf $>$ accessed 3 January 2016 14 . Met Office, 'Big Changes Underway in the Climate System?' (September 2015) 4-5 <http://www.metoffice.gov.uk/media/pdf/8/c/Changes_In_The_Climate_System.pdf $>$ accessed 3 January 2016.

15 Sands and Peel (n 10) 262-274.

16 Ibid 342-449. 
In an ideal world, States would come together and legislate a solution (as they appear to have done with success on the ozone layer (last month's New Yorker magazine ran an interesting profile of Cristiana Figueres, head of the UNFCC secretariat, which touched on the ozone issue, referring to a comment by F. Sherwood Rowland, a chemist who shared a Nobel Prize for the discovery of the ozone hole, who once reportedly came home from his lab and told his wife, "The work is going well, but it looks like it might be the end of the world"). ${ }^{17}$ Thus far real, effective global legislative action on climate change has proved to be elusive - the outcome of the negotiations to be held in Paris in December are awaited with trepidation and that is one reason why attention is increasingly being given to other means and other actors.

One of those potential actors is international courts, which have, until now, largely remained silent on the subject.

\section{PART III: INTERNATIONAL COURTS}

There are today a great number of international courts and tribunals - in excess of forty - so much so that it is impossible for any one person to keep up with the totality of their activity. This flowering is a recent development, one that has occurred since 1945, the moment at which the idea that international disputes could be settled by recourse to arbitration or judicial settlement truly took off, evoked by the chief prosecutor at Nuremberg, US Supreme Court associate justice Robert Jackson on November $21^{\text {st }} 1945$, the opening days of the trial, when he referred "the judgment of the law" as "one of the most significant tributes that Power has ever paid to reason". ${ }^{18}$

17 Elizabeth Kolbert, 'The Weight of the World' New Yorker (24 August 2015) < http://www.newyorker.com/magazine/2015/08/24/the-weight-of-the-world $>$ accessed 3 January 2016

${ }^{18}$ Nuremberg Military Tribunal, 2 IMT 98 (21 November 1945). On current challenges for international courts, see Philippe Sands, 'Developments - Developments in Geopolitics - The End(s) of Judicialization?' Keynote Final Lecture, 2015 European Society of International Law Annual Meeting (Oslo, 12 September 2015) Summary prepared by the Editors of Ejil:Talk! < http://www.ejiltalk.org/2015-esil-annual-conference-finallecture-developments-in-geopolitics-the-ends-of-judicialization/ > accessed 3 January 2016. 
Some of these courts are global, some are regional. Some are permanent, some are ad hoc. Each is unique, with its own rules, composition, working methods, and cases, and of course its distinct legal community of bar and scholars. Some are stronger, some are weaker, but they are all, in a sense, delicate and fragile creatures. Any comparison with national courts would be misplaced, since these have often had centuries to mature. (In conversations some years ago with the distinguished English legal historian Sir John Baker, he would remark that my modern world of international courts was probably akin to the situation that prevailed for English courts in the $15^{\text {th }}$ or $16^{\text {th }}$ century).

The point is, we are bound to limit our expectations. That does not mean, however, that we should not have some expectations, or hopes, that international courts might play a role.

There are courts of limited jurisdiction, and courts of more general jurisdiction. ${ }^{19}$ Their role is generally seen as being two-fold: (1) to resolve a particular dispute, and/or (2) to contribute to the developments of the rules of international law. There is too a third function, namely by their existence and activity to raise consciousness on a particular matter, to help us understand what needs to be done, or what is being done inadequately or not at all. International courts and tribunals may be purveyors of legitimacy.

The international courts and tribunals of limited jurisdiction may address - and in some cases already have addressed - issues of climate change within a limited prism. Thus, issues of climate change may arise before a number of international courts or tribunal concerning a violation of a treaty obligation or a contractual provision. A few examples illustrate.

The ECJ has addressed limited climate change issues,, 20 and human rights courts regularly address environmental issues of the kind that are associated with climate change - such as the right to life, health, private life, property $^{21}$ - as well as issues of forced migration and

19 See generally Ruth Mackenzie, Cesare Romano, Yuval Shany \& Philippe Sands, The Manual on International Courts and Tribunals (2nd edn, OUP 2010).

${ }^{20}$ E.g. Case C-366/10 Air Transport of America et al. v. Secretary of State for Energy and Climate Change (Grand Chamber) [2001] ECR II-864.

21 Alan Boyle, 'Human Rights and the Environment: Where Next?' (2012) 23 EJIL 613, 617-23. 
refugees. ${ }^{22}$ Yet the full complexities posed by climate change related issues may cause difficulties, as was reflected by the decision of the Inter-American Commission on Human Rights to dismiss an application brought on behalf of the Inuit of the United States and Canada in relation to alleged effects of greenhouse gas emissions on their livelihoods. Questions posed by the Commission in the course of that limited proceeding illustrate the challenges that lie ahead:

- how should the responsibility among states in the region (or even states that are not members of the OAS) be attributed or divided?

- could violations allegedly suffered by the Inuit be tied more closely to concrete acts or omissions of specific states?

- had the petitioners exhausted domestic remedies?

- what examples of good practices undertaken by states could guide the Commission in making its recommendations. ${ }^{23}$ The questions resonate more broadly.

Issues of climate change could also come up before the WTO Dispute Settlement Body, and in investor state disputes, with respect to legal challenges to measures taken by states that are aimed at addressing climate change might be challenged on the grounds they are expropriatory or discriminatory, or constitute unfair or inequitable treatment. I have sat on at least one such arbitration at the PCA - not in the public domain - involving measures taken in relation to the Kyoto Protocol Clean Development Mechanism. ${ }^{24}$

The point is that matters of climate change can may and do already arise before a variety of international courts or tribunals, but where this occurs the treatment of the subject will invariably be limited to the application of a particular international convention (or contract), and to a discrete issue. The questions posed by the Inter-American Commission in the Inuit case, and the fact that the Commission declined to proceed, suggests that such bodies might

\footnotetext{
22 Jane McAdam, Climate Change, Forced Migration, and International Law (OUP 2012).

23 Megan Chapman, 'Climate Change And the Regional Human Rights Systems' (2010) 10:2 Sustainable Development Law \& Policy 37, 38 and endnotes 26-29 < http://digitalcommons.wcl.american.edu/cgi/viewcontent.cgi?article $=1031 \&$ context $=$ sdlp $>$ accessed 3 January 2016.

24 Detailed information as to the role of the PCA is available at: http://www.pcacpa.org/showpagea7cf.html?pag_id=1029; see also Judith Levine \& Nicola Peart, 'Environmental Dispute Resolution: Experience of the PCA' (2015, unpublished).
} 
only ever have a limited role, unlikely to contribute in a material way to a broader response to the real challenges we face.

What about international courts or tribunals of more general jurisdiction, those which can apply treaties but also general international law (i.e. customary law)?

I have in mind here the International Court of Justice in The Hague, and the International Tribunal for the Law of the Sea in Hamburg.

The ICJ might be invited to address a question that goes to the heart of the issue: what is the responsibility of a state (or several states) for contributing to climate change, or for failing to give effect to an obligation under general international law to prevent the adverse consequences of climate change. Or it might focus on the legal content, if any, of the commitment agreed at Cancun in 2010 to limit global temperature increases to less than 2 degrees Celsius. Such a case could be contentious (i.e. one state brings proceedings against another for causing climate change; or failing to prevent adverse consequences, such as sea level rise or forced mass migration; or its responsibility to address such consequences, including the reception of forced migrants or environmental refugees). Or it could be advisory: what, if any, are the obligations under general international law to prevent climate change or mitigate its adverse consequences?

ITLOS might address a more limited issue, yet arising under the rubric of general international law: what is the responsibility of an UNCLOS party to prevent sea-level rise? Or its responsibility to take certain measures to mitigate against the consequences of climate change? Again, one could envisage a contentious case, or an advisory case.

The possible role of the ICJ or ITLOS raises broader questions about the nature and function of international courts. Is their job merely to interpret and apply the law, or to do something more, to contribute to the progressive development of the law (as Professor Lauterpacht considered), or even to inform the developments of an international public consciousness on matters of global concern? 
A broader approach would recognise that international courts and tribunals are one amongst many actors that occupy the large space in which global public consciousness is formed. In this way the international courtroom may be a place to forge international legitimacy. The ICJ has already played this function in the environmental field: in 1996, in the Advisory Opinion on Nuclear Weapons, the Court ruled that "the environment is not an abstraction but represents the living space, the quality of life and the very health of human beings, including generations unborn", ${ }^{25}$ and that "the general obligation of States to ensure that activities within their jurisdiction and control respect the environment of other States or of areas beyond national control is now part of the corpus of international law relating to the environment". ${ }^{26}$ Such a conclusion might seem obvious today, but it certainly was not in 1996, challenged even by a prominent academic not a million miles from Oxford. With the Court's decision it was no longer possible to argue that the protection of the environment was not governed by rules of general international law.

The ICJ - along with other international courts and tribunals - can and do play a useful role in developing the law, and contributing to a change of consciousness, and these developments can in turn catalyse new and needed actions: by states, by international organisations, by the private sector, by NGOs, and by individuals. A clear statement by a body such as the ICJ - as to what is or is not what required by the law, or as to what the scientific evidence does or does not require - may itself contribute to change in attitudes and behaviour. My favourite example is the announcement made by the Japanese company Rakuten, posted on its website the day after the ICJ gave its judgment that Japan's "scientific whaling" was unlawful, a judgment that was directed only to Japan and had nothing to say about retail sales. The announcement said:

"In accordance with the March 31, 2014 ruling by the International Court of Justice, Rakuten Ichiba today asked merchants to cancel sales of whale meat products on the Rakuten Ichiba marketplace." 27

\footnotetext{
25 Legality of the Threat or Use of Nuclear Weapons (n 4) [29].

${ }^{26}$ Ibid.

27 'Rakuten Updates Guidelines Regarding Items for Japan Marketplace' $(1 \quad$ April 2014 ) <http://global.rakuten.com/corp/news/press/2014/0401_04.html> accessed 3 January 2016.
} 
Whether we think such courts might actually do something useful in relation to climate change is another matter altogether, and it is to that which I now turn.

\section{PART IV: THE PROSPECTS FOR INTERNATIONAL JUDICIAL INVOLVEMENT}

In assessing the prospects for an intervention by the ICJ or ITLOS it is appropriate to reflect on four distinct (but related) factors.

First, the question of standing to bring a matter to the ICJ or ITLOS.

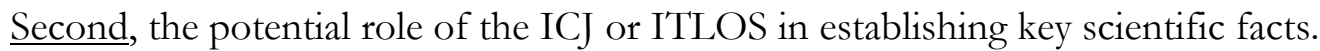

Third, their role in identifying the law, and indicating how it might be applied to the facts.

And fourth, their propensity to engage actively with the issues presented to it.

I will deal briefly with each of these factors.

\section{Standing}

The climate change case brought to the Rechtbank Den Haag was brought by a nongovernmental organisation, called Urgenda. The Dutch court had no difficulty ruling that this NGO had a sufficient legal interest to bring the case, to give effect to its object and purpose, which included the protection of a 'sustainable society'. ${ }^{28}$ At the international level, before the $\mathrm{ICJ}^{29}$ or ITLOS, $\frac{30}{\text { no }}$ NGO would have such a standing to initiate proceedings which

${ }_{28}$ Rechtbank Den Haag (n 9) [4.4]-[10].

${ }^{29}$ Following article 96 of the UN Charter the Security Council, the General Assembly and authorised UN agencies may request the Court to render an Advisory Opinion on any legal question of international law (Charter of the United Nations (24 October 1945) 1 U.N.T.S. XVI, art. 96; ICJ Statute, art. 65(1)). The Court has broadly construed the UNGA and UNSC's faculty stating that the former can submit requests on issues even on issues beyond its decision-making powers - the only limit being that the question is of a 'legal' nature (Legality of the Threat or Use of Nuclear Weapons (n 4) [12]-[13]). Conversely, the Court has construed the 
might help identify the obligations of states and other international actors to protect present

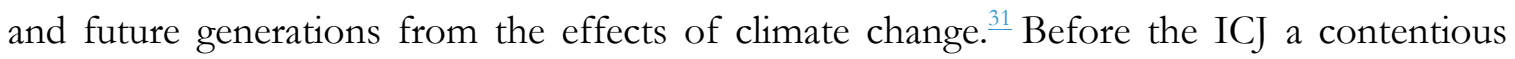
case would have to be brought by one State against another (at ITLOS the EU too could be a party). For both, an advisory opinion would have to be requested by an international organisation having the requisite authority.

A contentious case would be contentious, as I have mentioned, and in that sense less attractive. If there were an inclination, it would also be possible for one state that had accepted the compulsory jurisdiction of the Court to bring proceedings against another in relation to a failure to meet an obligation under general international law.

I doubt it would be too problematic for a state party to an international convention to bring a case against another state party (assuming there is a jurisdictional basis - only Cuba and The Netherlands have accepted the jurisdiction of the ICJ to resolve disputes under the 1992 Convention, and only the Solomon Islands and Tuvalu have accepted compulsory arbitration). ${ }^{32}$ Last year the ICJ had no trouble finding that it had jurisdiction to entertain the claim brought by Australia against Japan, to review Japan's whaling activity in the Antarctic by reference to the requirements of scientific research under the 1946 International Whaling

specialised agencies' faculty in an overly narrow manner by linking the scope of requests to its constitutive instrument's object and purpose. Thus, under the speciality principle invoked by the Court in denying the WHO request in the Nuclear Weapons procedures (before the UNGA stepped in with its own request), it follows that no specialised agency's mandate would allow it to submit a comprehensive question regarding the legal implications of climate change. (Legality of the Use by a State of Nuclear Weapons in Armed Conflict (Request by WHO) ICJ Rep 1996 [18]-[31]).

30 Article 288 UNCLOS establishes that "a court or tribunal referred to in article 287 [i.e., ITLOS, the ICJ, an Annex VII or VIII tribunal] shall have jurisdiction over any dispute concerning the interpretation or application of [UNCLOS]". Although advisory jurisdiction is not expressly provided for in UNCLOS, ITLOS found it had the authority to render such opinions following article 21 of its Statute: it held that the term all "matters" ('toutes les fois que cela') refers not only to 'disputes' - which regard the contentious jurisdiction of the tribunal - but "something more": advisory opinions provided for in "any other agreement which confers jurisdiction on the Tribunal." Advisory Opinion on a Request for an Advisory Opinion Submitted by the Sub-Regional Fisheries Commission (2 April 2015) ITLOS [53]-[60].

${ }^{31}$ ITLOS has however opened room for NGO participation in advisory proceedings: in Responsibilities and Obligations of States sponsoring persons and entities with respect to activities in the Area (Request for Advisory Opinion submitted to the Seabed Disputes Chamber) the Tribunal's Registry informed two NGOs that, although their amicus briefs would not be added to the file, it was to be posted the on the tribunal's website and provided its transmission to states and intergovernmental organisations taking active participation in the proceedings. See $<$ https://www.itlos.org/cases/list-of-cases/case-no-21/\#c1276> accessed 3 January 2016.

32 See Declarations of States Parties to the UNFCCC Parties
$<$ http://unfccc.int/essential_background/convention/items/5410.php $>$ accessed 3 January 2016. 
Convention. ${ }^{33} \mathrm{I}$ suppose Cuba could bring a case against the Netherlands, alleging for example that the latter has failed to comply with the obligation to meet the objective of the 1992 Convention set forth in its Article 2, although such a case would have an element of artifice about it.

The difficulty would be the crushingly vague nature of the obligations, invariably drafted in such a way as to make it impossible to argue that any particular provision gives rise to a cause of action (one of the most notable provisions of that Convention is the footnote added to Article 1 (entitled "Definitions"), which provides that "Titles of articles are included solely to assist the reader": this footnote is aimed at the title to Article 3 (entitled "Principles"), to make it clear that although the content of the five sub-paragraphs of Article 3 are called principles, they are in fact not to be treated as legal principles, and not of a nature to give rise to an actionable remedy).

The alternative to a contentious case is an advisory opinion. The UN General Assembly and a number of specialised agencies have been empowered to make requests for advisory opinions to the ICJ. By Article 138 of its Rules ITLOS has accorded itself the power to give an advisory opinion on a legal question if an international agreement related to the purposes of the Convention specifically provides for the submission to the Tribunal of a request for such an opinion. It has recently exercised that power - by unanimous decision - in relation to a request from an African sub-regional fisheries commission, and in doing so rejected stiff objections as to its jurisdiction, argued by several states, including the United Kingdom. ${ }^{34}$

Such requests are rarely declined, although in 1996 the ICJ did refuse to accede to a request from the WHO on the legality of the use of nuclear weapons (it acceded to a parallel request from for the UN General Assembly). It is not immediately apparent why the ICJ would not respond to a request for an advisory opinion from the UN General Assembly. Equally, one could envisage ITLOS acceding to a request from a broad range of organisations - global or regional - that touched on a legal question relating to UNCLOS and climate change.

\footnotetext{
${ }^{33}$ Whaling in the Antarctic case (Australia v. Japan, New Zealand Intervening) ICJ Rep 2014 [30]-[41].

34 Advisory Opinion on a Request for an Advisory Opinion Submitted by the Sub-Regional Fisheries Commission (n 28).
} 


\section{The Facts}

What facts might the ICJ or ITLOS be required to address? That of course would depend on the precise case brought to the court, and its form (contentious proceedings or advisory opinion). To be of any potential utility, I would have thought the ICJ or ITLOS could usefully address a number of underlying, central factual issues that are essentially of a scientific or technical nature, and perhaps requiring the assessment of expert evidence. A first tier of issues might include: is climate change underway? have sea-levels risen? Have anthropogenic greenhouse gas emissions been the main cause of atmospheric warming? I appreciate that many in this room will consider these facts already to have been established, but the reality is that some still challenge them. It is one thing for the IPCC to come to such conclusions as a matter of scientific opinion, but quite another for an international court to give them the authority of a judicial determination of the facts.

A second tier of matters for factual determination might be more specific. The ICJ or ITLOS could be asked, for example, to confirm (as a scientific matter) that emissions reductions are needed - nationally and globally - to stay below the globally agreed temperature threshold of 2 degrees Celsius.

As I noted at the outset, there is a broad emerging consensus on many of these factual matters, but they remain subject to challenge in some quarters, including by scientifically qualified, knowledgeable and influential persons.

One the most important things an international court could do - in my view it is probably the single most important thing it could do - is to settle the scientific dispute. A finding of fact on one or more of these matters, or indeed on other pertinent matters, would be significant and authoritative and could well be dispositive on range of future actions, including negotiations. A finding of fact by the ICJ would be of great authority in proceedings before other international courts and tribunals, and before national courts. That has been made clear by last year's ruling by the ICJ that Japan's programme of whaling could not properly be characterised as "scientific whaling" within the meaning of the 1946 Convention. The judgment was given in the face of sharply differing opinions in the 
Scientific Committee of the IWC: a less robust court might have concluded that there was no settled view on the matter, and it was not for the court to take a view.

The ICJ did not follow that path. That it chose to engage with competing scientific claims is much to its credit. Remarkably this was the first case ever in which there was crossexamination of the scientific experts put forward by Australia and Japan. In earlier cases the Gabcikovo-Nagymaros case between Hungary and Slovakia on harm to the Danube, ${ }^{35}$ and in the Pulp Mills case between Argentina and Uruguay on alleged pollution of the shared Uruguay River ${ }^{36}$ - scientific experts acted as counsel, and were not subject to crossexamination or questioning by the Court. In the Whaling case the Court changed its approach, and I (and many others who were present in the room during the hearings) were very clear that such examination and questioning was the key to the Court reaching the conclusions it did: that the issuance of whaling permits involving the use of lethal methods did not comply with the 'scientific research' requirement. ${ }^{37}$ The way in which that process was carried out, and conclusions taken from it by the Court, have gone a long way in increasing comfort levels that the Court has a potentially significant role to play in helping the world understand the science of climate change, and to recognise that the room for real doubt has disappeared.

\section{The Law}

As with the facts, the legal issues to be addressed will depend on the precise wording of any request for an advisory opinion that may be put to the Court. There are so many different variations of what is possible that it hardly seems useful to speculate as to possibilities. I will therefore limit what I have to say by focusing on what might actually be useful.

As to the temporal aspect, I would take some persuading that it would be in any material way useful to dwell or focus on the past, on issues of historic responsibility. That was a problem with the request being considered a few years back.

\footnotetext{
35 Case Concerning the Gabcikovo-Nagymaros Project (Hungary/Slovakia) 1997, para 53.

${ }^{36}$ Case Concerning Pulp Mills on the River Uruguay (Argentine v. Uruguay) 2010, paras 167-68.

37 Whaling in the Antarctic case (Australia v. Japan, New Zealand Intervening) 2014, para 67.
} 
The purpose of an advisory opinion, if there is to be one, is surely to benefit the international community as a whole, by looking forward. What is to be done, rather than what has been done (although I recognise there is a connection between the two elements). That can best be done by identifying two things at least: first, the law this applicable to the matter? and second, how does that applicable law in general terms apply to the multitude of issues that will surely arise as climate change and its consequences bear their unhappy fruit. Separately from that, it may be possible, useful and desirable, to invite the Court to express a view as to the content of any existing obligation under international law on the actions of States on, for example, the nature and extent of the duty or obligation to prevent climate change, and the nature and extent of the duty or obligation under international law to address the consequences of climate change.

Let me say something briefly on each aspect.

As to the applicable law, the Court could be asked to deal both with the obligations that arise under treaties in force (1992 UNFCC, 1997 Kyoto Protocol etc.) and general international law. The interrelationship between different sources of legal obligation is not necessarily straightforward, or settled.

It may be, for example, that States have a duty under general international law to act in such a way as to prevent climate change, or climate change beyond a particular threshold. Thus, there is now a political commitment emissions of carbon dioxide should be limited to ensure that global temperatures do not increase beyond two degree Celsius (and some states, the most vulnerable, believe the threshold to be set at a lower level of 1.5 degrees Celsius). Many are asking: does that commitment reflect an obligation under international law?

There is also the matter of the application of the ILC articles on the responsibility of states for internationally wrongful acts, which is reflects, in large part, general international law. The relationship between the 1992 Convention and the law of state responsibility was explicitly recognised when that convention was opened for signature: a number of small island states made declarations to the effect that their ratification of the Convention "shall in no way constitute a renunciation of any rights under International Law concerning State 
responsibility for the adverse effects of Climate Change as derogating from the principles of general International Law.",38

Article 1 of the ILC articles provides that "Every internationally wrongful act of a State entails the international responsibility of that State". ${ }^{39}$ Article 2 specifies that an internationally wrongful occurs where "conduct consisting of an action or omission: (a) is attributable to the State under international law; and (b) constitutes a breach of an international obligation of the State." ${ }^{40}$ Some are asking: at what point could it be said that the occurrence of climate change actually breach an international obligation?

Relatedly, if there is an obligation, and if it has been breached, and the breach is attributable to one or more states, what are the consequences? The ILC Articles refer to an obligation to cease the act, if it is continuing, and not to repeat it (Article 30), and to make full reparation for the injury caused by the internationally wrongful act (Article 31). What might these requirements mean in relation to climate change and the consequences thereof? What is the relevance of the principle of joint and several liability? "Where several States are responsible for the same internationally wrongful act", Article 47 provides, "the responsibility of each State may be invoked in relation to that act." ${ }^{41}$ What consequence, if any, does the principle have for the allocation of further obligations between states, having regard to the need to achieve an equitable distribution of the burdens? And what is equitable, in all the circumstances? That is a question that an international court should be well placed to answer, and it does answer it in relation to other matters, such as maritime boundary delimitation.

These are important questions, and not necessarily easy to answer. Once again, looking to the future, the law can play a role, in outlining the bases upon which certain measures are to be taken. Clarifying the law could contribute to a greater sense of solidarity amongst states and other international actors, including the corporate sector. In the face of legislative inertia,

\footnotetext{
38 See declarations by Fiji, Kribati, Nauru, Papua New Guinea, Tuvalu: available at UN Treaty Collection: https://treaties.un.org/pages/ViewDetailsIII.aspx?src=TREATY\&mtdsg_no=XXVII7\&chapter $=27 \&$ Temp $=$ mtdsg $3 \&$ lang $=$ en

${ }^{39}$ ICL, 'Draft articles on Responsibility of States for Internationally Wrongful Acts' (2001) A756/10, art. 1

${ }^{40}$ Ibid, art. 2.

${ }^{41} \mathrm{Ibid}$, art. 47.
} 
given the political and economic and other consequences, might an international court or tribunal be likely to act?

\section{The Propensities of the Court}

In a certain sense it might be said that any international court or tribunal, like its domestic counterpart, is no more than the sum of its parts present (namely the judges that sit on it), and historic (namely its past practise). With an ICJ judge sitting within hitting distance of me, I proceed with caution.

ITLOS has recently shown itself willing - in the area of fisheries - to exercise the power to give an advisory opinion in the filed of fisheries conservation. Its recent opinion points the One day after the ICJ ruled against Japan in the whaling case, the EU; matters of liability; and the nature and extent of the obligation to cooperate on the conservation of shared fisheries resources. The advisory opinion has been generally well received, and offers a marker as to what I possible.

In relation to the ICJ, I confess that I have been somewhat sceptical as to its potential role on the climate change issue. However, my view has evolved.

First, the Court's track record has been significant in recent years, in the sense of being positive in enhancing the place of environmental protection in sensitive areas. There is a clear line from the 1996 advisory opinion on the legality of nuclear weapons through to the 2014 judgment in the whaling case. The Court has a record on the environment of which it can be proud.

Second, the Court's bench is as strong today as at any time in which I have known it.

Third, the issue of climate change may no longer be one in which the great powers are at odds, or in which the interests of North and South necessarily collide, 
And fourth, the Court faces active competition from other courts, including ITLOS and the re-emergence of inter-state arbitration. That might make the Court more rather than less likely to rise to one of the greatest and most vital challenges of our age. It could act to make a positive contribution, or it could choose to remain silent and consign itself to irrelevance, in which case states and people and other actors will no doubt look elsewhere.

\section{PART V: CONCLUSIONS}

Let me now draw together the strings. Climate change poses a significant challenge, and international law will play a central role in defining our ability to meet that challenge. I am not starry-eyed about international courts, but they do and should have a role to play, in helping to resolve dispute, in contributing to the development in the law, in raising public consciousness, and in offering workable, effective solutions that have the special authority of the law to back them.

No doubt some useful role could be played by contentious litigation, but this is surely the kind of domain in which the advisory role of international courts and tribunals might be most useful, building on the increased engagement of their domestic counterparts, developing consensus, looking forward rather than backwards, offering clarification rather than pointing fingers of blame.

Given the prospect of increases in ocean temperatures, sea-level rise and the disappearance and land territory, ITLOS is an obvious place to bring a request for an advisory opinion on matters that relate to the obligations of states and international organisations on the protection of the oceans. I have every confidence that ITLOS would meet the challenge, and could offer a most useful contribution.

But it would inevitably be a contribution that was limited in its scope, and only the ICJ, the principal judicial organ of the United Nations, has the jurisdiction and authority to deal - in theory at least - with the totality of the key legal questions that arise in relation to climate change. In the context of the forthcoming negotiations in Paris, where a positive outcome 
would nevertheless leave many legal questions open, the time is surely right for a sensibly worded resolution of the General Assembly of the United Nations, requesting the ICJ that it give an advisory opinion on the future obligations of states and other actors - by convention and general international law - in relation to climate change. Such an opinion would need to focus not only on the prevention of further adverse effects, but also on the mitigation of those effects, and in particular the issue of burden sharing. The events of the past weeks in Europe, in relation to forced migrants and refugees, underscores the consequences of a failure to have a proper framework to deal with crises of these kinds, and the terrible human consequences. Appalling as the current situation is, it will be as nothing compared to what climate change may bring.

On the subject of prevention, I think we need to go further. In the Urgenda case, the Dutch court ruled that "it is currently very probable that within several decades dangerous climate change will occur with irreversible consequences for man and the environment". To that end, it gave a judgment that was based on the need to limit the rise of global temperatures to below 2 degrees Celsius above pre-industrial levels. ${ }^{42}$

The ICJ too could play a role in relation to that target, one based on science. It could be asked to confirm, for example, that the 2 degrees Celsius target now reflects an obligation under international law, and that its implementation imposes obligations to reduce emissions, including if necessary by phasing out altogether certain emissions of carbon dioxide and other greenhouse gases.

In addressing such an opinion, there is also no reason why the Court could not, within its rules of procedure, open up the process, allowing not only states and international organisations, but also other actors who are stakeholders, including corporations and NGOs, to participate by some effective means. There is nothing in the Court's rules to preclude it from doing that, especially if the General Assembly so requested.

My Lords and Ladies, ladies and gentlemen,

${ }^{42}$ Urgenda judgment, para. 4.32. 
Many years ago, Lord Atkin, a judge of this Court, noted that "in England, amidst the clash of arms, the laws are not silent". 43

I hope that that sentiment - which was a minority view then but is now widely accepted as correct - might offer inspiration in relation to the real and imminent challenges of climate change.

In our world, amidst the warming of the atmosphere, and the melting of the ice, and the rising of the seas, the international courts shall not be silent.

Thank you for your kind attention.

${ }^{43}$ Liversidge v Anderson [1941] UKHL 1. 